\title{
Detection of Structural Change of Superoxide Dismutase in Solution
}

\author{
Yuji Chiba, Yuichi Sutoh, and Yuzo Nishida* \\ Department of Chemistry, Faculty of Science, Yamagata University, Yamagata 990-8560, \\ Japan. Fax: +81-023-628-4591. E-mail: yuzo@sci.kj.yamagata-u.ac.jp \\ * Author for correspondence and reprint requests \\ Z. Naturforsch. 61 c, 273-277 (2006); received November 2, 2005
}

\begin{abstract}
We have confirmed that dissociation of the dimeric SOD molecule into a monomeric one can be readily detected in solution by the use of capillary electrophoresis (CE), which is based on the fact that the peak height in the CE profile is highly dependent on the aggregation conditions of the protein molecule. Based on this fact, it has become apparent that the hydrogen peroxide molecule induces the dissociation of the dimeric structure of SOD, and this should give reasonable explanation for the inactivation of SOD by hydrogen peroxide. Our results may give a convenient way for the early detection of the amyotrophic lateral sclerosis in patients, because we can estimate whether the SOD molecule is of a rigid or loosed dimeric structure by the use of this technique. The loosed one has been assumed to exhibit inherent toxicity of the copper center, so-called "gain-of-function" of the mutant
\end{abstract} SOD.

Key words: SOD, Capillary Electrophoresis, Dissociation of Dimeric Structure

\section{Introduction}

$\mathrm{Cu}, \mathrm{Zn}$ superoxide dismutases (Cu,Zn-SODs) are metalloenzymes involved in the mechanism of cellular defense against oxidative damage (Fridovich, 1975; Hough and Hasnain, 1999). They have been found in the cytoplast of all the eukaryotic cells and in the periplasm of several bacterial species. Eukaryotic $\mathrm{Cu}, \mathrm{Zn}$-SODs are homodimers that contain one atom of zinc and one atom of copper per subunit and catalyze the dismutation of the superoxide anion at a diffusion-limited rate enhanced by electrostatic guidance of the substrate to the active site (Hough and Hasnain, 1999).

Amyotrophic lateral sclerosis (ALS), also known as Lou Gehrig's disease, is a neurodegenerative disorder characterized by the destruction of large motor neurons in the spinal cord and brain (Okado-Matsumoto and Fridovich, 2002). Approx. $5-10 \%$ of cases are familial and $15-25 \%$ of familial ALS cases are associated with dominantly inherited mutations in SOD1 (Deng et al., 1993; Cudkowicz and Brown, 1996; Jeneja et al., 1997). Initially, 11 different missence mutations in 13 different FALS families were identified. These were found to cluster in a region critical for maintaining the three-dimensional architecture of the human $\mathrm{Cu}, \mathrm{Zn}$-SOD protein, namely at the homodimer interface and in the loop region at the ends of $\beta$ strands. It is now clear that in FALS the human
$\mathrm{Cu}, \mathrm{Zn}$-SOD molecule is affected in a global sense, and SOD1 mutations identified in FALS are present in all exons, and five different mutations are seen in codon 93 of exon 4.

The mechanism by which single amino acid changes in the SOD molecule lead to FALS is not yet understood. Recent studies indicate that two of the human FALS mutants, A4V and G93A, catalyze the oxidation of a model substrate by hydrogen peroxide at higher rates than that seen with the wild-type enzymes (Widau-Pazos et al., 1996; Yim et al., 1996, 1997), and the chemical origin for the above facts were clearly elucidated by us in terms of the model compounds (Nishino et al., 2001a; Nishida, 2004). Hart et al. (1998) have determined the crystal structure of a human $\mathrm{Cu}, \mathrm{Zn}$ SOD mutant G37R ( $\mathrm{Cu}, \mathrm{Zn}$-SOD) found in some patients with the inherited form of ALS, and reported that two SOD subunits have distinct environments in the crystals and are different in structure at their copper binding sites. They suggested that the copper site asymmetry leads to loosing of the protein structure, the dissociation of the dimeric structure, which may de-repress the inherent toxicity of the copper center (Hart et al., 1998). The origin of this inherent toxicity, so-called "gainof-function" of the mutant SOD, can be elucidated similarly as described by the present authors (Nishino et al., 2001a; Nishida, 2004).

The structural data of the SOD molecules have been studied mainly in the crystal states (Hough 
and Hasnain, 1999; Hart et al., 1998; Chille et al., 1997), however it is necessary to develop a new technique to investigate the dissociation of the dimeric structure of the SOD molecule in solution. It was reported that monomeric and dimeric conformers of the SOD enzyme can be separated by gel filtration FPLC column (D'Orazio et al., 2000). Very recently we have reported that the capillary electrophoresis (CE) method is very suitable to detect the dissociation process of dimeric structure of several proteins including SOD in solution (Kishita and Nishida, 2004; Sutoh et al., 2005). In this study we have measured the $\mathrm{CE}$ profiles of the solutions containing $\mathrm{Cu}, \mathrm{Zn}-\mathrm{SOD}$ in the presence or absence of metal chelates or hydrogen peroxide in order to get more information on the structural changes of SOD in solution.

\section{Materials and Methods}

\section{Materials}

SOD was purchased from Sigma (bovine, S2515). Several metal chelates were used in this study; the chemical structures of the ligands are illustrated below. Metal chelates, $\left[\mathrm{Ni}(\mathrm{D}\right.$-glen $) \mathrm{Cl}_{2}$ (Yano et al., 1985), $\left[\mathrm{Ni}(\text { dien })_{2}\right] \mathrm{Cl}_{2}($ dien $=$ diethylenetriamine), $\mathrm{Fe}_{2}$ (HPTP) $\mathrm{Cl}_{4} \mathrm{ClO}_{4}$ (Nishino et al., 1999), $\quad \mathrm{Zn}_{2}$ (HPTP) $\left(\mathrm{CH}_{3} \mathrm{COO}\right)_{2} \mathrm{ClO}_{4}$ (Nishino et al., 2001b) and $\mathrm{Co}_{2}(\mathrm{HPTP})\left(\mathrm{CH}_{3} \mathrm{COO}\right)\left(\mathrm{ClO}_{4}\right)_{2}$ (Nishida et al., 1999), were obtained according to the published methods; H(HPTP) represents $N, N, N^{\prime}, N^{\prime}$-tetrakis(2-pyridylmethyl)-1,3-diaminopropanol.

D-glen

dien

$\mathrm{NH}_{2} \mathrm{CH}_{2} \mathrm{CH}_{2} \mathrm{NHCH}_{2} \mathrm{CH}_{2} \mathrm{NH}_{2}$

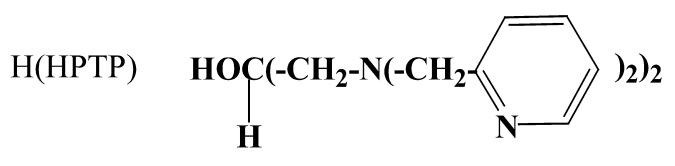

\section{Capillary electrophoresis (CE)}

Capillary electrophoregrams of the solutions were obtained with a Beckman/Coulter P/ACE MDQ instrument; temperature, $298 \mathrm{~K}$; buffer solu-

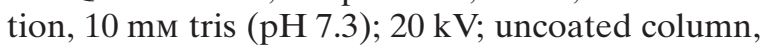
I.D. $50 \mu \mathrm{m}, 50 \mathrm{~cm}$; detection, $214 \mathrm{~nm}$. Three solutions, $50 \mu \mathrm{l}$ (SOD, $2 \mathrm{mg} / 1 \mathrm{ml}$ ), $50 \mu \mathrm{l}$ (tris-buffer, $\mathrm{pH} 7.3$ ), and $10 \mu \mathrm{l}$ metal complex, or hydrogen peroxide, were mixed and eluted with tris-buffer

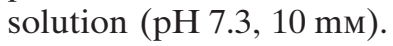

\section{Results and Discussion}

\section{$C E$ profiles of $S O D$ in the presence of metal chelates}

In our previous paper, the CE profiles of SOD and transferrin were compared (Sutoh et al., 2005). The two solutions of the proteins with equal concentration showed quite different $\mathrm{CE}$ profiles, especially the peak heights. This was elucidated in our previous papers as follows (Kishita and Nishida, 2004; Sutoh et al., 2005); the structural freedom should be lower in the dimeric SOD molecule compared with that of the transferrin, leading to

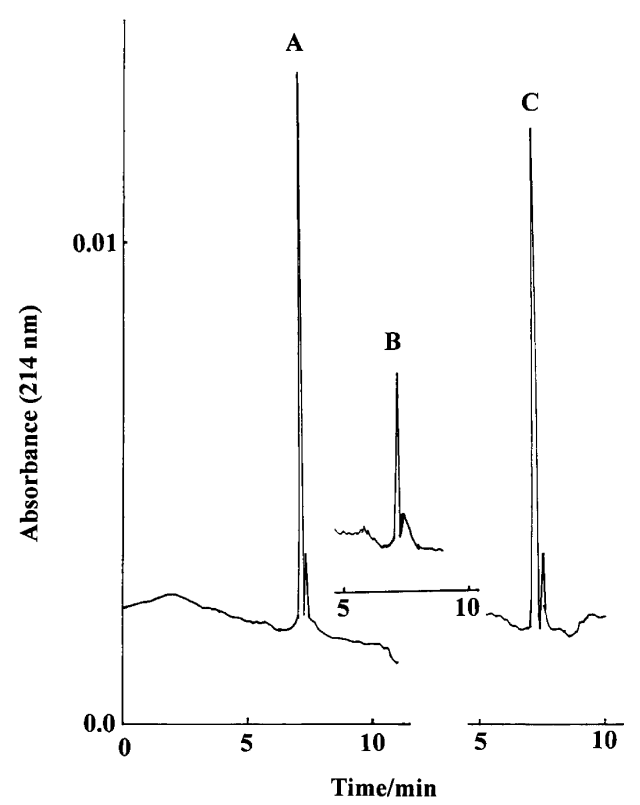

Fig. 1. CE profiles of the solutions containing SOD and $\left[\mathrm{Ni}(\mathrm{D} \text {-glen })_{2}\right] \mathrm{Cl}_{2}$. A: SOD $(100 \mu \mathrm{l} ; 0.5 \mathrm{mg} / 1 \mathrm{ml}$ solution $)$. B: Nickel(II) complex solution $(10 \mu \mathrm{l} ; 2 \mathrm{mg} / 1 \mathrm{ml}$ solution) was added to the solution of SOD (100 $\mu \mathrm{l} ; 0.5 \mathrm{mg}$ / $1 \mathrm{ml}$ solution), and measurement was done immediately after mixing. C: Measurement $60 \mathrm{~min}$ after the mixing. 
the smaller numbers of possible conformers of the SOD protein in solution (James and Tawfik, 2003), which is reflected as a sharper signal in CE profile. Based on the above consideration, we proposed that the $\mathrm{Mn}(\mathrm{dpgt}) \mathrm{Cl}_{2}$ complex reacts with SOD in solution, leading to the dissociation of the protein, and the dissociated SOD molecules gradually rebind to give the original dimeric structure (Sutoh et al., 2005). In this study completely the same phenomenon as observed for the $\mathrm{Mn}(\mathrm{dpgt}) \mathrm{Cl}_{2}$ complex was observed by the addition of [Ni(Dglen) $] \mathrm{Cl}_{2}$ complex to the solution of SOD (see Fig. 1; the peak at $7 \mathrm{~min}$. is attributed to the SOD molecule), but the recovery of the peak height to the original one was not attained $(\sim 50 \%$ recovery) by the addition of $\left[\mathrm{Ni}(\operatorname{dien})_{2}\right] \mathrm{Cl}_{2}$ complex (data not shown).

The similar phenomenon as observed for the $\mathrm{Mn}(\mathrm{dpgt}) \mathrm{Cl}_{2}$ complex was observed in the presence of metal chelates with $\mathrm{H}(\mathrm{HPTP})$. The addition of $\left[\mathrm{Co}_{2}(\mathrm{HPTP})\left(\mathrm{CH}_{3} \mathrm{COO}\right)\right]^{2+}$ complex immediately induced a decrease of the peak

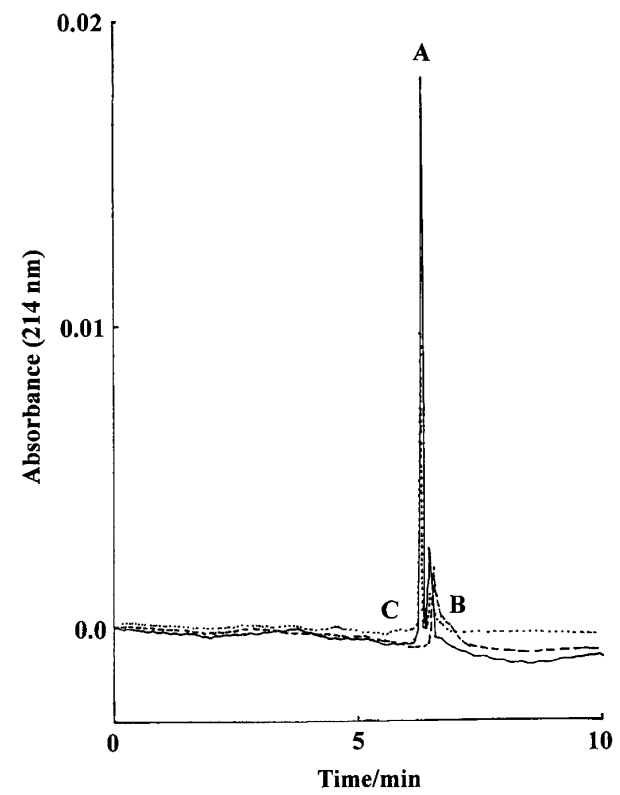

Fig. 2. CE profiles of the solutions containing SOD and $\mathrm{Co}_{2}$ (HPTP $)\left(\mathrm{CH}_{3} \mathrm{COO}\right)\left(\mathrm{ClO}_{4}\right)_{2}$. A: SOD $(100 \mu \mathrm{l} ; 0.5 \mathrm{mg} /$ $1 \mathrm{ml}$ solution). B: Cobalt(II) complex solution (10 $\mu \mathrm{l}$; $2 \mathrm{mg} / 1 \mathrm{ml}$ solution) was added to the solution of SOD $(100 \mu \mathrm{l} ; 0.5 \mathrm{mg} / 1 \mathrm{ml}$ solution), and measurement was done immediately after mixing. C: Measurement $2 \mathrm{~h}$ after the mixing. height of SOD ( $10 \%$ of the original one), and the peak height approached to $\sim 60 \%$ of the original one after 2 hours (Fig. 2). In the cases of $\left[\mathrm{Fe}_{2}(\mathrm{HPTP}) \mathrm{Cl}_{4}\right]^{+}$and $\left[\mathrm{Zn}_{2}(\mathrm{HPTP})\left(\mathrm{CH}_{3} \mathrm{COO}\right)_{2}\right]^{+}$ complexes, the reduction of the peak height proceeded similarly, but peak heights $(\sim 15 \%$ of the original one) did not change after long time.

\section{$C E$ profiles of $S O D$ in the presence of hydrogen peroxide}

As shown in Fig. 3, the addition of hydrogen peroxide to the SOD solution induced the reduction of the peak height of the CE profiles, and the peak height never came back to the original one. The reduction of the peak height is dependent on the concentration of the hydrogen peroxide, i.e., the higher the concentration of the hydrogen peroxide solution, the larger the reduction of peak height is, and notable reduction begins to be observed when $\left[\mathrm{H}_{2} \mathrm{O}_{2}\right]$ became 5 times over of the copper(II) ions concentration of the SOD molecule.

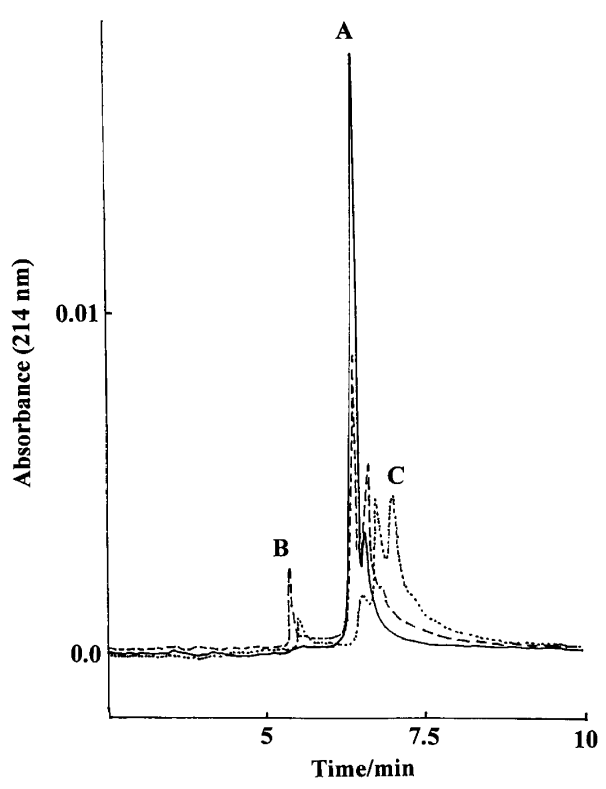

Fig. 3. CE profiles of the solutions containing SOD and hydrogen peroxide. A: SOD $(100 \mu \mathrm{l} ; 0.5 \mathrm{mg} / 1 \mathrm{ml}$ solution). B: Hydrogen peroxide solution $(10 \mu \mathrm{l})$ was added to the solution of SOD $(100 \mu \mathrm{l} ; 0.5 \mathrm{mg} / 1 \mathrm{ml}$ solution $)$, and in the resulted solution the relation $\left[\mathrm{H}_{2} \mathrm{O}_{2}\left[=5\left[\mathrm{Cu}^{2+}\right]\right.\right.$ holds. The measurement was done immediately after mixing. C: Measurement $1 \mathrm{~h}$ after the mixing. 


\section{New method for early detection of ALS patients}

In the Introduction, we have written that Hart et al. (1998) have determined the crystal structure of a human $\mathrm{Cu}, \mathrm{Zn}-\mathrm{SOD}$ mutant G37R $(\mathrm{Cu}, \mathrm{Zn}$ SOD) found in some patients with the inherited form of ALS, and reported that two SOD subunits have distinct environments in the crystals and are different in structure at their copper binding sites. They also suggested that the copper site asymmetry leads to loosing of the protein structure, the dissociation of the dimeric structure. It is wellknown that the addition of hydrogen peroxide to the dimeric SOD induces the reduction of one of the two copper(II) ions to copper(I) state (Lio-

Chille G., Falconi M., Amadei A., Zimatore G., Desideri A., and Nola D. (1997), The essential dynamics of $\mathrm{Cu}, \mathrm{Zn}$ superoxide dismutase. Suggestion of intersubunit communication. Biophys. J. 73, 1007-1018.

Cudkowicz M. E. and Brown R. H. (1996), An update on sueproxide dismutase 1 in familial amyotrophic lateral sclerosis. J. Neurol. Sci. 139, 10-15.

Deng H. X., Hentati A., Tainer J. A., Iqbal Z., Cayabyab A., Hung W. Y., Getzoff E. D., Hu P., Herzfeldt B., Roos R. P., Warner C., Deng G., Soriano E., Smyth C., Parge H. E., Ahmed A., Roses A. D., Hallewell R. A., P.-Vance M. A., and Siddique T. (1993), Amyotrophic lateral sclerosis and structural defects in $\mathrm{Cu}, \mathrm{Zn}$ superoxide dismutase. Science 261, 10471051.

Fridovich I. (1975), Superoxide dismutase. Annu. Rev. Biochem. 44, 147-159.

Hart P. J., Liu H., Pellegrini M., Nersissian A. M., Grallia E. B., Valenteine J. S., and Eisenberg D. (1998), Subunit asymmetry in the three-dimensional structure of a human $\mathrm{Cu}, \mathrm{Zn}-\mathrm{SOD}$ mutant found in familial amyotrophic lateral sclerosis. Protein Sci. 7, 545-555.

Hough H. A. and Hasnain S. S. (1999), Crystallographic structures of bovine copper-zinc superoxide dismutase reveal asymmetry in two subunits: Functionally important three and five coordinate copper sites captured in the same crystal. J. Mol. Biol. 287, 579592.

James L. C. and Tawfik D. S. (2003), Conformational diversity and protein evolution - a 60-year-old hypothesis revisited. Trends Biochem. Sciences. 28, $361-$ 368.

Jeneja T., P.-Vance M. A., Laing N. G., Dave S., and Siddique T. (1997), Prognosis in familial amyotrophic lateral sclerosis: Progression and survival in patients with glu100gly and ala4val mutations in $\mathrm{Cu}, \mathrm{Zn}$ superoxide dismutase. Neurology 48, 55-57.

Kishita A. and Nishida Y. (2004), Binding of two glycoproteins in solution detected by capillary electrophoresis. Annu. Rep. CIN. 3, 1-6. chev and Fridovich, 2002); this means that site asymmetry is induced by the addition of hydrogen peroxide. The above discussion seems to be consistent with our results, i.e., the peak height reduction of the SOD molecule occurs in the CE profile by the addition of hydrogen peroxide, as illustrated in Fig. 3. This will give a convenient method to investigate the structural feature of SOD molecule in solution, i.e., when we compare the CE profile of the SOD molecule in the presence or absence of the hydrogen peroxide, and if the peak heights due to the SOD molecule are the same in both the solutions, we can say that the tested SOD is of a loosed structure, which should be dangerous.

Liochev S. L. and Fridovich I. (2002), Copper,Zinc superoxide dismutase and $\mathrm{H}_{2} \mathrm{O}_{2}$. J. Biol. Chem. 277, 34674-34678.

Nishida Y. (2004), Oxidative stress and neurodegeneration. Med. Hypothesis Res. 1, 227-245.

Nishida Y., Nishino S., Guo L. L., Kunita M., Matsushima H., and Tokii T. (1999), DNA promotes the activation of oxygen molecule by binuclear cobalt(II) compounds. Inorg. Chem. Commun. 2, 438-441.

Nishino S., Kunita M., Kobayashi T., Matsushima H., Tokii T., and Nishida Y. (1999), Interaction between the peroxide adduct of binuclear iron(III) complex with (HPTP) anion and the sugar moiety of nucleosides. Z. Naturforsch. 54b, 1272-1276.

Nishino S., Kishita A., and Nishida Y. (2001a), Alternative origin for "gain-of- function" by mutant SOD enzyme and for conformational change of normal prion protein. Z. Naturforsch. 56c, 1144-1149.

Nishino S., Kobayashi T., Matsushima H., Tokii T., and Nishida Y. (2001b), Enhanced nucleophilicity and depressed electrophilicity of peroxide by zinc(II), aluminum(III) and lanthanum(III) ions. Z. Naturforsch. 56c, $138-143$.

Okado-Matsumoto A. and Fridovich I. (2002), Amyotrophic lateral sclerosis: A proposed mechanism. Proc. Natl. Acad. Sci. USA 99, 9010-9014.

D’Orazio M., Battistoni A., Stroppolo M. E., and Desideri A. (2000), Single mutation induces a metal-dependent subunit association in dimeric $\mathrm{Cu}, \mathrm{Zn}$ superoxide dismutase. Biochem. Biophys. Res. Commun. 272, $81-63$.

Sutoh Y., Nishino S., and Nishida Y. (2005), Metal chelates to prevent or clear the deposits of amyloid $\beta$ peptide $(1-40)$ induced by zinc chloride. Chem. Lett. 34, 140-141.

Wiedau-Pazos M., Goto J. J., Rabizadeh S., Gralla E. B., Loe J. A., Lee M. K., Valenteine J. S., and Bredesen D. E. (1996), Altered reactivity of superoxide dismutase in familial amyotrophic lateral sclerosis. Science 271, 515-518. 
Yano S., Sakai Y., Toriumi K., Ito T., Ito H., and Yoshikawa S. (1985), Reactions of metal complexes with carbohydrates: isolation and characterization of novel nickel(II) complexes containing $\mathrm{N}$-glycoside ligands derived from amino sugars. Inorg. Chem. 24, 498-504. Yim M. B., Kang J. H., Yim H. S., Kwak H. S., Chock P. B., and Stadtman E. R. (1996), A gain-of-function of an amyotrophic lateral sclerosis-associated $\mathrm{Cu}, \mathrm{Zn}$ superoxide dismutase mutant: An enhancement of free radical formation due to a decrease in $\mathrm{Km}$ for hydrogen peroxide. Proc. Natl. Acad. Sci. USA 93, 5709-5714.

Yim H. S., Kang J. H. Chock P. B., Stadtman E. R., and Yim M. B. (1997), A familial amyotrophic lateral sclerosis-associated $\mathrm{A} 4 \mathrm{~V} \mathrm{Cu}, \mathrm{Zn}$-superoxide dismutase mutation has a lower Km for hydrogen peroxide. Correlation between clinical severity and the $\mathrm{Km}$ value. J. Biol. Chem. 272, 8861-8863. 